\title{
United States Minor Outlying Islands
}

National Cancer Institute

\section{Source}

National Cancer Institute. United States Minor Outlying Islands. NCI Thesaurus. Code C20112.

The U.S. Minor Outlying Islands consist of Baker Island, Howland Island, Jarvis Island, Johnston Atoll, King man Reef, Midway Island, Navassa Island, Palmyra Atoll, and Wake Island (Wake Atoll). 